\title{
Learning and teaching gender and sexuality issues in the EFL classroom: Where students and teachers stand
}

\section{Reiko Yoshihara}

\author{
Nihon University
}

This paper explores the gap between teachers and students' attitudes toward learning about domestic violence and gay/lesbian issues in the EFL classrooms in a Japanese university. Results showed that students had positive feelings toward learning about domestic violence and gay/lesbian issues, whereas college instructors were sometimes hesitant or disliked teaching about these issues. Students had an intellectual curiosity toward these issues and indicated the connection between learning about these issues and personal growth. On the other hand, instructors showed a lack of confidence or anxiety about discussing these issues in their classrooms.

本論では、大学のEFL教室における、家庭内暴力と同性愛問題に対す る学生と教師の意識の違いを研究した。結果として、学生はこれらのトピ ックを学ぶことに好意的であったのに対し、教師はその重要性を認識し ながらも、あまり積極的には取り上げたくないという反応がみられた。学 生はジェンダーやセクシュアリティの問題に対する知的好奇心を示し、学 ぶことは自己成長につながると述べた。一方、教師はこれらの問題を教 えることに対する不安や自信のなさを示した。

or decades, the use of sociopolitical issues, including gender and sexuality issues, as a topic in an ESL/EFL course has been debated in the field of TESOL (see Benesch, 1993, 2001; Santos, 1992, 2001). Critical and feminist ESL/EFL pedagogues have asserted that teaching about global issues, gender issues, and sexuality issues in ESL/EFL programs is important (for global issues, see Cates, 2002; Peaty, 2004; for gender issues, see Benesch, 1998; Saft \& Ohara, 2004; Vandrick, 1995, 1998; Yoshihara, 2010; for sexuality issues, see Nelson, 1999, 2004; O'Mochain, 2006; Summerhawk, 1998). On the other hand, several ESL/EFL scholars criticized the use of these sociopolitical issues in the language classroom as indoctrination and argued that ESL/EFL teachers should focus on grammar, vocabulary, and rhetorical forms (Allison, 1994;

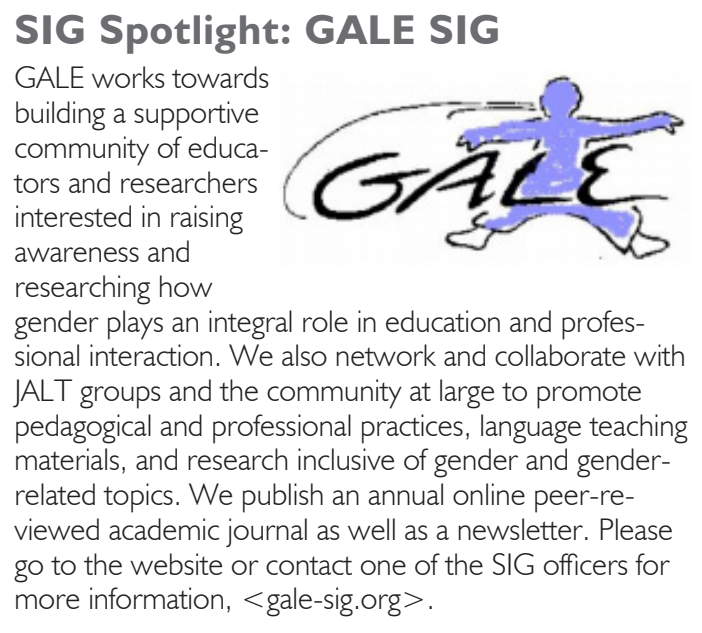

GALE works towards building a supportive community of educators and researchers interested in raising awareness and researching how gender plays an integral role in education and professional interaction. We also network and collaborate with JALT groups and the community at large to promote pedagogical and professional practices, language teaching materials, and research inclusive of gender and genderrelated topics. We publish an annual online peer-reviewed academic journal as well as a newsletter. Please go to the website or contact one of the SIG officers for more information, <gale-sig.org $>$.

Reid, 1989; Santos, 1992, 2001; Smith, 1997). Along with critical and feminist pedagogues' assertions, I hold that teaching sociopolitical issues including gender and sexuality issues should not be criticized as indoctrination. Rather, critical and feminist teaching are both needed and appropriate in ESL / EFL settings for raising the consciousness of all students toward equality and social justice.

In this study, I narrow the focus to teaching about gender and sexuality issues in EFL college classrooms in Japan. I investigated students' and teachers' perceptions toward learning and teaching about these issues in the EFL classrooms.

\section{Methods}

\section{Participants}

In two EFL writing classes during the 2009 academic year and two in the 2010 academic year, 97 students (62 male, 35 female) who 
majored in business at a private Japanese university participated in this study. All student participants were similar in terms of English language learning background. In terms of EFL college instructor participants, there were 33 (9 male, 24 female) teaching in the Kanto area. They were Japanese college English professors and instructors between the ages of 36 and 75 . Their specialties varied among such fields as TESOL, English and American literature, cultural studies, and linguistics.

\section{Materials and procedures}

As a teacher-researcher, I taught four EFL writing classes at the college (two in 2009 and two in 2010). The course comprised six topics in themebased language instruction: English learning, domestic violence, global warming, gay/lesbian issues, the rights of the child, and corporate social responsibility. To investigate students' topic preference and perception toward learning about gender and sexuality issues in the EFL classroom, I conducted an item questionnaire with a 6-point Likert scale as well as an open-ended questionnaire. Then, I chose 12 students for interviews. Follow-up interviews were conducted by email. To investigate instructors' topic preference and perception toward teaching about gender and sexuality issues in their classrooms, I made another item questionnaire with a 6-point Likert scale followed by an open-ended questionnaire. I chose 5 instructor participants for email or telephone interviews.

\section{Results}

Table 1 shows students' and instructors' topic preferences. I conducted a one-way ANOVA to explore if there was any significant difference between students and instructors.
Statistical comparison of students' and instructors' preferences on topics

Students' and instructors' topic preferences refer to how much students like to learn about these six topics and how much instructors want to teach these same topics. The ANOVA shows that there were significant differences between students and instructors on domestic violence $(p$ $=.000)$, global warming $(p=.004)$, gay / lesbian issues $(p=.000)$, the rights of the child $(p=.000)$, and corporate social responsibility $(p=.007)$. However, the most significant mean differences were between students and instructors on domestic violence $(1.67, p<.005)$ and gay / lesbian issues $(1.36, p<.005)$.

\section{Students' perceptions toward learning about gender and sexuality issues}

In open-ended questionnaires and interviews, many students expressed positive feelings toward learning about gender and sexuality issues. Several students showed intellectual curiosity and awareness about domestic violence and gay / lesbian issues in the open-ended questionnaires. They commented that they had no opportunity to learn about these issues in other classes, so they were glad to learn about these issues in the English classroom. Even in interviews, several students mentioned that domestic violence and gay/lesbian issues were not discussed in high school textbooks, so they had not learned about these issues before. One male student mentioned, in an interview, that he wanted to learn about something new and interesting. Thus, gender and sexuality issues stimulated the intellectual curiosity of students.

Also, students became more aware of their own misconceptions by learning about gender

Table I. Means, standard deviation, and one-way analyses of variance (ANOVA) on topics: Students versus instructors

\begin{tabular}{|l|c|c|c|c|c|c|}
\hline \multirow{2}{*}{ Topics } & \multicolumn{2}{|c|}{ Students $(N=97)$} & \multicolumn{2}{|c|}{ Instructors $(N=33)$} & \multicolumn{2}{c|}{ ANOVA } \\
\cline { 2 - 7 } & $M$ & $S D$ & $M$ & $S D$ & $F(1,128)$ & $\eta 2$ \\
\hline English Learning & 4.38 & 1.40 & 3.76 & 1.35 & 4.97 & .04 \\
\hline Domestic Violence & 4.85 & 1.16 & 3.18 & 1.29 & $48.03^{*}$ & .27 \\
\hline Global Warming & 4.66 & 1.23 & 3.91 & 1.33 & $8.77^{*}$ & .06 \\
\hline Gay / Lesbian Issues & 4.57 & 1.35 & 3.21 & 1.43 & $24.18^{*}$ & .16 \\
\hline The Rights of the Child & 4.92 & 1.07 & 4.09 & 1.28 & $13.29^{*}$ & .09 \\
\hline Corporate Social Responsibility & 4.96 & 1.28 & 4.24 & 1.37 & $7.42^{*}$ & .06 \\
\hline
\end{tabular}

Note. $\eta 2=$ effect size. ${ }^{*} p<.01$. 
and sexuality issues. As for domestic violence, several students previously held misconceptions and had adopted victim-blaming attitudes. They assumed that domestic violence occurs only in low-income families, that battered women might be at fault because they stayed in a violent relationship, and that domestic violence is very rare. However, after they learned about domestic violence, they realized the misconceptions and changed their perceptions toward those who were/ had been battered. As for gay / lesbian issues, some students confessed that they had a prejudice against gays and lesbians. Then, some made comments, "By learning about gay / lesbian issues, I changed my perception towards gays and lesbians" and "I learned about gay/ lesbian issues in this class by reading materials and watching videos, and wanted to understand them more than before" (From open-ended questionnaires). They became aware of their own prejudices and changed perceptions toward sexual minorities as a result of their classroom experiences. Learning about gender and sexuality issues led students to awareness of these issues, personal growth, and open-mindedness.

\section{Instructors' perceptions toward teaching gender} and sexuality issues

According to the responses to open-ended questionnaires, many were positive about using social, cultural, and global issues as topics in an EFL class. One instructor commented that she wanted students to learn about others and other countries and cultures in the EFL classrooms. Another instructor mentioned that social and cultural issues should be introduced in an EFL classroom to enrich students' education and mind. However, one female instructor, while acknowledging the importance of introducing social issues, human rights, and global issues, expressed a concern about possible indoctrination by mentioning, "We try not to indoctrinate students and should be careful about introducing these issues" (From an open-ended questionnaire).

Several instructors agreed that it would be important to bring gender and sexuality issues into an ESL/EFL classroom but expressed some hesitation, or even opposition toward introducing domestic violence or gay/lesbian issues. They mentioned that they did not have sufficient knowledge of these issues, so they preferred not to introduce them in their classrooms. In a telephone interview, one female instructor said that she did not have enough materials about gay / lesbian issues, so she was not confident in teaching the issues. On the other hand, another female EFL instructor who was positive about teaching about domestic violence and gay / lesbian issues said that she had knowledge and information about these issues, so she was confident in discussing them with students (from an email communication). Thus, it seems that for teachers the amount of knowledge and information about the topic affects the decision-making process regarding a decision to teach gender issues.

Another issue that prevents instructors from introducing gender and sexuality issues is anxiety over unexpected consequences. In email communications, one male instructor had expressed a concern about the risk of a violation of privacy and the possibility of disclosure of sexual orientation in his classroom. In a telephone interview, another female instructor said that if one of her students confessed unexpectedly that he/she was gay/lesbian, she would not know how to deal with it. Thus, teachers seemed to worry about the unexpected consequences of discussing delicate topics in their classrooms.

\section{Conclusion}

This study revealed the gaps between students and teachers regarding their attitudes toward learning about and teaching gender and sexuality issues in an EFL classroom. While students were interested in learning about gender and sexuality issues, EFL instructors were less keen to use these topics in their language classrooms. For EFL instructors, teaching domestic violence and gay/lesbian issues is fairly challenging in their classrooms and creates a feeling of anxiety for some teachers. However, I believe that it is important for ESL / EFL instructors to teach about gender equality and social justice in the classrooms because what happens in the classroom is not separated from what happens in our society. Teaching about gender and sexuality issues evokes insights, enriches students' educational experience, and may even change their lives. It may lead to personal and, from there, to social change. The language classroom should not be regarded as an apolitical site, but rather a site for consciousness-raising and personal and social change. 


\section{References}

Allison, D. (1994). Comments on Sarah Benesch's "ESL, ideology, and the politics of pragmatism": A reader reacts. TESOL Quarterly, 28, 618-623.

Benesch, S. (1993). ESL ideology, and the politics of pragmatism. TESOL Quarterly, 27, 705-717.

Benesch, S. (1998). Anorexia: A feminist EAP curriculum. In T. Smoke (Ed.), Adult ESL: Politics, pedagogy, and participation in classroom and community programs (pp. 101-114). Mahwah, New Jersey: Lawrence Erlbaum Associates.

Benesch, S. (2001). Critical English for academic purposes: Theory, politics, and practice. New York, NY: Routledge.

Cates, K. (2002). Teaching for a better world; Global issues and language education. Human Rights Education in Asian Schools, 5, 41-52.

Nelson, C. (1999). Sexual identities in ESL: Queer theory and classroom inquiry. TESOL Quarterly, 33, 371-391.

Nelson, C. (2004). Beyond straight grammar: Using lesbian/gay themes to explore cultural meanings. In B. Norton \& A. Pavlenko (Eds.), Gender and English language learners (pp. 15-28). Alexandria, VA: Teachers of English to Speakers of Other Languages.

O'Mochain, R. (2006). Discussing gender and sexuality in a context-appropriate way: Queer narratives in an EFL college classroom in Japan. Journal of Language, Identity, and Education, 5(1), 51-66.

Peaty, D. (2004). Global issues in EFL: Education or indoctrination? The Language Teacher, 28(8), 15-18.

Reid, J. (1989). English as a second language composition in higher education: The expectations of the academic audience. In D. M. Johnson \& D. H. Roen (Eds.), Richness in writing: Empowering ESL students (pp. 220-234). New York: Longman.

Saft, S., \& Ohara, Y. (2004). Promoting critical reflection about gender in EFL classes at a Japanese university. In B. Norton \& A. Pavlenko (Eds.), Gender and English language learners (pp. 143-154). Alexandria, VA: Teachers of English to Speakers of Other Languages.

Santos, T. (1992). Ideology in composition: L1 and ESL. Journal of Second Language Writing, 1, $1-15$.

Santos, T. (2001). The place of politics in second language writing. In T. Silva \& P. K. Matsuda
(Eds.), On second language writing (pp. 161-190). Mahwah, NJ: Erlbaum.

Smith, J. (1997). Students' goals, gatekeeping, and some questions of ethics. College English, 59, 299-320.

Summerhawk, B. (1998). From closet to classroom: Gay issues in ESL/EFL. The Language Teacher, 22(5), 21-23.

Vandrick, S. (1995). Teaching and practicing feminism in the university ESL class. TESOL Journal, 4(3), 4-6.

Vandrick, S. (1998). Promoting gender equity in the postsecondary ESL class. In T. Smoke (Ed.), Adult ESL: Politics, pedagogy, and participation in classroom and community programs (pp. 73-88). Mahwah, New Jersey: Lawrence Erlbaum Associates.

Yoshihara, R. (2010). Teaching women's issues in an EFL classroom: What do students learn? Eibeibunka, 40, 229-242.

This essay first appeared in Journal and Proceedings of the Gender Awareness in Language Education (Special Interest Group of the Japan Association for Language Teaching), 4, pp. 5-20. For this publication, it was shortened and edited.

\section{Reiko Yoshihara is an} Associate Professor in the College of Commerce at Nihon University in Japan. Her research interests include feminist pedagogy in education, feminist teaching in ESL/EFL classes, and teachers' cognition.

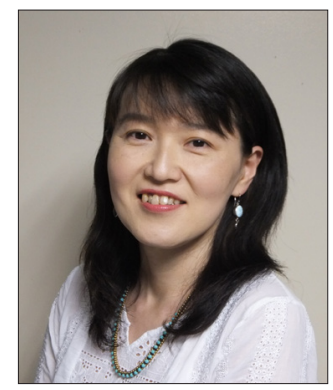

\section{JALT Tokyo Chapter - Language Teaching Policy \& Planning Lecture \& Workshop Series, October 2013 - January 2014 Lecture speakers include Penny Ur, Sandra Mackay, and Kensaku Yoshida}

Chapter members will lead workshops and discussion sessions. The series kicks off October 23 with Penny Ur's "Teaching Large, Heterogeneous Classes." All events will be held at Sophia University, Yotsuya campus. See $<$ tokyojalt.org $>$ for more information. 